\begin{tabular}{|c|c|c|}
\hline & Int.J.Curr.Microbiol.App.Sci (2018) 7(11): 1156-1164 & \multirow{2}{*}{ 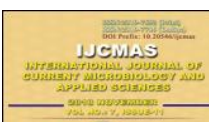 } \\
\hline & \multirow{3}{*}{$\begin{array}{l}\text { International Journal of Current Microbiology and Applied Sciences } \\
\text { ISSN: 2319-7706 Volume } 7 \text { Number } 11 \text { (2018) } \\
\text { Journal homepage: http://www.ijcmas.com }\end{array}$} & \\
\hline & & \\
\hline $\begin{array}{l}\text { EXCELLENT } \\
\text { PUBL ISHERS }\end{array}$ & & \\
\hline
\end{tabular}

\title{
Identification and Characterization of Bacterial Isolates from Bovine Calves with Respiratory Affections
}

\author{
Stephanie S. Pradhan* and Vipan Kumar Gupta
}

CSKHPAU, DGCN COVAS, Palampur, Himachal Pradesh, India

*Corresponding author

\begin{tabular}{|l|}
\hline Ke y w or d s \\
$\begin{array}{l}\text { Bovine calf, Respiratory } \\
\text { affections, Bacterial } \\
\text { isolates, Himachal } \\
\text { Pradesh }\end{array}$ \\
\hline Article Info \\
$\begin{array}{l}\text { Accepted: } \\
\text { 10 October } 2018 \\
\text { Available Online: } \\
10 \text { November } 2018\end{array}$ \\
\hline
\end{tabular}

Calves are important assets of the poor dairy farmers as they play a major role in uplifting their socio-economic condition. Calfhood diseases are the major cause of economic losses in livestock, one of the most important being respiratory affections. The present work was conducted to investigate the bacterial entities responsible for respiratory affections in bovine calves in Palampur Valley of Himachal Pradesh, India. Samples were collected asceptically from the nasal cavity using sterile nasal swabs from 51 sick and apparently healthy animals from Palampur and its surrounding districts. Standard microbiological techniques were used for isolation and identification of bacterial isolates. In between the sampling period eleven calves showing moderate to severe respiratory signs succumbed and the necropsy examination revealed lesions of pneumonia in all eleven cases. From a total of 51 samples, 46 yielded bacterial isolates with two cases showing mixed infection, hence a total of 48 isolates were obtained. The common isolates obtained from the nasal passages were E. coli (45.83\%), Streptococcus. sp (27.08\%), Staphylococcus. sp (14.58\%), Citrobacter. sp (12.5\%). Screening of nasal bacterial flora from the sick animals was done in order to determine the prevalence and to provide better treatment to further sustain animal life.

\section{Introduction}

Calves are important assets of the poor dairy farmers as they play a major role in uplifting their socio-economic condition. In India over $65 \%$ of the population still lives in rural areas where majority of them are small and marginal landholders (Mahendra, 2014). As livestock is the major source of their livelihood, successful rearing of the young calves exclusively determines the profitability of the dairy farms and the farmers. Radostits (2001) have roughly estimated that a calf mortality of $20 \%$ may reduce net profit by $38 \%$. The total number of cattle in India as per 2012 census is 190.90 million contributing around $37.28 \%$ to the total livestock population. According to the $18^{\text {th }}$ livestock census (2007) the total bovine population in Himachal Pradesh (HP) was 3.03 million, which is approximately $1 \%$ of India's bovine population. Highest mortality has been recorded highest in calves $(21.53 \%)$ followed by young stocks $(9.35 \%)$ and adults $(4.73 \%)$ (Chaudhary et al., 2013). Calf mortality and morbidity has been mostly attributed to 
respiratory affections and digestive disorders (Prasad et al., 2004; Mishra et al., 2015). Respiratory affections have been known to increase by $34 \%$ in the last 20 years with $21 \%$ neonatal mortality (NAHMS 2007).

Pneumonia is one of the major respiratory infections which take a heavy toll on the life of the calves during their first few months of life (Svensson et al., 2006; Ramakrishna et al., 2008, Gulliksen et al., 2009a). Calfhood disease has the potential to reduce daily gains and affect the age at first calving. Virtala et al., (1996) found that each week of pneumonia decreased body weight gain by $0.8 \mathrm{~kg}$ per day during the first 3 months of their lives. Anatomical and physiological features of the respiratory system of calves also predispose them to the development of pneumonia much more than other species (Veit and Farrel, 1978). Calf pneumonia is a multifactorial disease, involving interplay of infectious agents such as viruses, bacteria, mycoplasma and parasites, managerial errors, stressors and host susceptibility. Among bacteria the common ones affecting are Mannheimia haemolytica and Pasteurella multocida.

Pasteurella species is a normal inhabitant of the upper respiratory tract that causes acute bronchopneumonia. A switch from commensal to pathogen takes place when the organism proliferates due to variety of stress factors. Pathogens commonly isolated from the calves dying of pneumonia are Pasteurella multocida, Mannheimia haemolytica, Arcanobacterium pyogenes, Escherichia coli, $\alpha$ and $\beta$ haemolytic Streptococcae (Trigo et al., 1982; Taoudi et al., 1983; Svensson et al., 2006; Singh et al., 2009). Despite availability and use of many antimicrobial drugs calf morbidity and mortality still remains an important cause of economic losses on dairy farms worldwide. Therefore in current scenario, a regular monitoring for respiratory affections is of prime importance.
Thus the present study was conducted to identify the major bacterial entities responsible for respiratory affections in bovine calves so that prophylactic measures and better treatment could be met accordingly to further sustain the animal life.

\section{Materials and Methods}

\section{Experimental design}

Sampling was done from sick or ailing calves showing respiratory affections from the University farm of CSKHPAU, Government Jersey farm and surrounding districts of Palampur, Himachal Pradesh. Till date no report of respiratory affections has been reported from Himachal Pradesh hence this study was undertaken to determine the prevalence of bacterial entities.

\section{Collection of samples}

Nasal swabs were collected from the sick calves showing respiratory signs with nasal discharge and dull and depressed demeanor (Table 1). Sample collection was done for the period $15^{\text {th }}$ June 2015 to $22^{\text {nd }}$ June 2016. The number of samples collected from sick calves of both sexes was 51. Samples were collected using sterile polystyrene cotton swabs dipped in nutrient broth. External nares were cleaned by mopping with spirit swabs to clean the discharges before the swab was passed through nares, penetrated deep into the meatus and rotated firmly and smoothly in a circular fashion against the mucosa (Barnum et al., (1969). The swabs were taken to the laboratory for further processing for bacteriological studies within 1-2 hours of collection.

\section{Isolation}

The samples collected from the ailing calves using sterile swabs were cultured invariably 
on the same day. The primary isolation was done on blood agar by streaking the swab over the blood agar plates. This was carried out under the laminar flow and incubated aerobically at $37^{\circ} \mathrm{C}$ for $16-24$ hours to check for any microbial growth. The smears prepared from the purified colonies were subjected to Gram's staining and the morphological features of isolates were studied under the microscope.

\section{Identification of isolates}

Gram positive isolates were identified on the basis of colonial morphology, microscopic examination and biochemical characteristics (catalase, oxidase and motility). Staphylococcus sp was further streaked onto mannitol salt agar. Sugar fermentation tests were carried out for the gram positive isolates for species level identification (Table 2) (Carter and Cole, 1990)

In order to identify the gram negative isolates, they were streaked on McConkey Lactose bile salt Agar (MLA) and incubated for 16-24 hours to distinguish enterobacteria group i.e. lactose fermenters from non-lactose fermenters.

The lactose fermenting colonies were further streaked on Eosin methylene blue (EMB). All isolates were subjected to routine biochemical fermentation reactions for their confirmation (Table 3).

\section{Maintenance of cultures}

The purified isolates were inoculated into Brain Heart Infusion (BHI) broth and incubated at $37^{\circ} \mathrm{C}$ for $24-48$ hours. $50 \%$ glycerol stock was prepared in sterile cryovials by mixing equal volume of the culture with equal volume of sterilized glycerol and preserved at $-20^{\circ} \mathrm{C}$ for further use.

\section{Results and Discussion}

A total of 51 samples (nasal swabs) from clinically sick animals were collected from different farms.

Out of 51, 46 (92\%) samples yielded bacterial isolates with two cases showing mixed infection. Therefore a total of 48 (96\%) bacterial isolates were obtained.

11 out of 51 calves succumbed to respiratory illness in due course of time. Necropsy examination was performed and the following results were obtained (Table 4).

\section{Identification of bacteria}

After the primary isolation in blood agar, the cultures were observed for colonial morphology and then subjected to gram staining followed by biochemical tests (Table 5).

\section{Gram positive isolates}

For gram positive bacteria observations were made based on the morphology, nature of haemolysis and fermentation of sugars. The results of fermentation of sugars together with the nature of haemolysis were used in species level identification (Table 6 and 7).

\section{Enterobactericeae}

The gram negative rods were subjected to the following biochemical tests (Table 8) for distinction between the enterobacteriaceae.

E.coli was further streaked onto Eosin Methylene Blue (EMB) for re-confirmation.

Hence the bacteria isolated from the clinically sick were E. coli (45.83\%), Streptococcus. sp (27.08\%), Staphylococcus. sp (14.58\%), Citrobacter. sp (12.5\%). 
Table.1 Age wise distribution of sick animals used for sample collection

\begin{tabular}{|c|c|c|c|c|c|c|}
\hline \multirow{2}{*}{$\begin{array}{l}\text { S. } \\
\text { No }\end{array}$} & \multirow[t]{2}{*}{ Source } & \multicolumn{4}{|l|}{ Age } & \multirow[t]{2}{*}{ Total } \\
\hline & & $<1$ month & 1-3 months & 3-6 months & 6-10 months & \\
\hline 1 & CSKHPAU dairy farm, Palampur & 22 & 3 & 1 & 2 & 28 \\
\hline 2 & Government Jersey farm, Palampur & 1 & 3 & Nil & Nil & 4 \\
\hline 3 & Field & 6 & 1 & 9 & 3 & 19 \\
\hline \multicolumn{2}{|c|}{ Total } & 29 & 7 & 10 & 5 & 51 \\
\hline
\end{tabular}

Table.2 Sugars used for identification of species of gram positive isolates

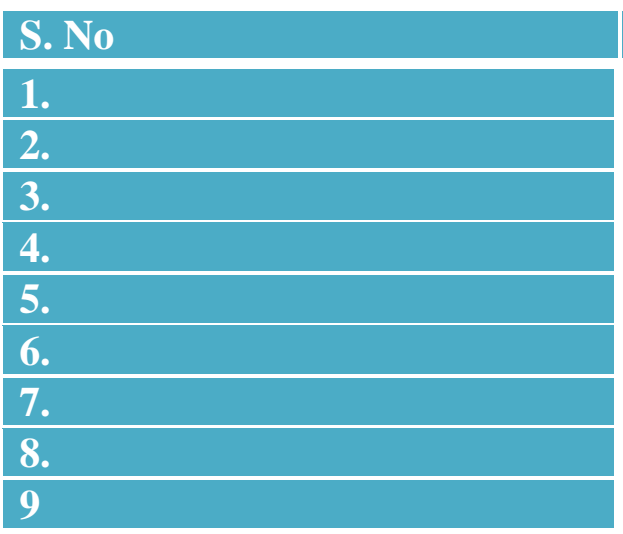
Sugars
Dextrose
Mannitol
Maltose
Trehalose
Sorbitol
Salicin
Lactose
Raffinose
Inulin

Table.3 Biochemical tests used for identification of bacteria belonging to Enterobacteriaceae family

\begin{tabular}{|l|}
\hline S. No \\
\hline 1 \\
\hline 2 \\
\hline 3 \\
\hline 4 \\
\hline 5 \\
\hline 6 \\
\hline 7 \\
\hline
\end{tabular}

\section{Biochemical Tests}

Indole production

Methyl Red

Voges-Proskaeur

Citrate utilization

Oxidase production

Catalase production

Motility

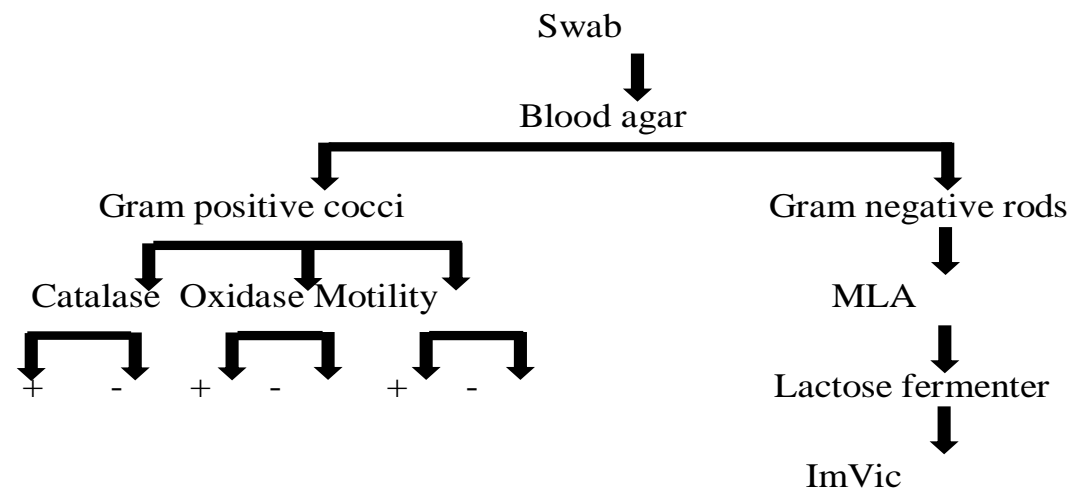


Table.4 Clinical cases that succumbed due to respiratory affection

\begin{tabular}{|c|c|c|c|c|c|c|}
\hline A. No & PM. No & $\begin{array}{l}\text { Age at } \\
\text { the time } \\
\text { of } \\
\text { sampling }\end{array}$ & $\begin{array}{l}\text { Clinical finding at } \\
\text { sampling }\end{array}$ & $\begin{array}{l}\text { Age at } \\
\text { the time } \\
\text { of death }\end{array}$ & Sex & $\begin{array}{l}\text { Diagnosis at } \\
\text { necropsy }\end{array}$ \\
\hline 788 & 3200/CTL/16 & $10 \mathrm{~d}$ & ND & $4 \frac{1}{2} 2 \mathrm{mo}$ & M & Interstitial pneumonia \\
\hline 4537 & 3193/CTL/16 & $1 \mathrm{mo} 4 \mathrm{~d}$ & ND & $5 \mathrm{mo}$ & $\mathrm{F}$ & Interstitial pneumonia \\
\hline 4538 & 3203/CTL/16 & $23 \mathrm{~d}$ & ND & $5 \frac{1}{2} \mathrm{mo}$ & $\mathrm{F}$ & Interstitial pneumonia \\
\hline 784 & 3188/CTL/16 & $10 \mathrm{~d}$ & ND \&diarrhoea & $6 \mathrm{mo}$ & M & Interstitial pneumonia \\
\hline 262 & 3189/CTL/16 & $14 d$ & ND & $6 \mathrm{mo}$ & M & Interstitial pneumonia \\
\hline 789 & 3213/CTL/16 & $9 \mathrm{~d}$ & ND & $6 \mathrm{mo}$ & M & Interstitial pneumonia \\
\hline 4532 & 3191/CTL/16 & $20 \mathrm{~d}$ & Apparently healthy & $6^{1 / 2} \mathrm{mo}$ & $\mathrm{F}$ & Interstitial pneumonia \\
\hline 261 & 3195/CTL/16 & $30 \mathrm{~d}$ & ND\& diarrhoea & $6^{1 / 2} \mathrm{mo}$ & M & Interstitial pneumonia \\
\hline 264 & 3226/CTL/16 & $10 \mathrm{~d}$ & ND\& diarrhoea & $6 \frac{1}{1} 2 \mathrm{mo}$ & M & Interstitial pneumonia \\
\hline 263 & 3229/CTL/16 & $22 \mathrm{~d}$ & ND & $7 \mathrm{mo}$ & M & Interstitial pneumonia \\
\hline 772 & 3173/CTL15 & 9 mo $8 d$ & Respiratory distress & $9 \mathrm{mo} 12 \mathrm{~d}$ & M & $\begin{array}{l}\text { Bronchopneumonia } \\
\text { with lungworms }\end{array}$ \\
\hline
\end{tabular}

$\mathrm{d}=$ day; $\mathrm{mo}=$ month; $\mathrm{M}=$ male $; \mathrm{F}=$ female $\mathrm{ND}=$ nasal discharge

Table.5 Biochemical tests for identification of bacteria

\begin{tabular}{|l|l|l|l|l|}
\hline Isolates & Gram stain & Catalase & Oxidase & Motility \\
\hline Streptococcus & Gram positive cocci (chains) & $-\mathrm{ve}$ & $-\mathrm{ve}$ & $-\mathrm{ve}$ \\
\hline Staphylococccus & Gram positive cocci (clusters) & $+\mathrm{ve}$ & $-\mathrm{ve}$ & $-\mathrm{ve}$ \\
\hline E.coli & Gram negative rods & $+\mathrm{ve}$ & $-\mathrm{ve}$ & $+\mathrm{ve}$ \\
\hline Citrobacter & Gram negative rods & $+\mathrm{ve}$ & $-\mathrm{ve}$ & $+\mathrm{ve}$ \\
\hline
\end{tabular}

Table.6 Sugars used for species level identification of Streptococcus. Sp

\begin{tabular}{|l|l|l|l|l|l|l|l|l|}
\hline Species & Haemolysis & Tre & Sb & Mn & Sa & La & Rf & In \\
\hline S. pyogenes & $\beta$ & + & - & + & + & + & - & - \\
\hline S. equi & $\beta$ & - & + & - & + & + & - & - \\
\hline S. bovis & $\alpha$ & + & - & + & + & + & + & + \\
\hline Enterococcus faecalis & $\alpha / \beta$ & + & + & + & + & + & - & - \\
\hline
\end{tabular}

$\mathrm{Tre}=$ trehalose $\mathrm{Sb}=$ sorbitol $\mathrm{Mn}=$ mannitol $\mathrm{Sa}=$ salicin $\mathrm{La}=$ lactose $\mathrm{Rf}=$ raffinose $\mathrm{In}=$ inulin

Table.7 Sugars used for species level identification of Staphylococcus. Sp

\begin{tabular}{|l|l|l|l|l|}
\hline Species & Haemolysis & Dextrose & Mannitol & Maltose \\
\hline Staphylococcus aureus & + & + & + & + \\
\hline Staphylococcus epidermidis & - & + & - & + \\
\hline Staphylococcus hyicus & - & - & - & +
\end{tabular}

The cultures were streaked onto mannitol salt agar for re-confirmation of Staphylococcus aureus. 
Table.8 ImVic used for identification of enterobacteriaceae

\begin{tabular}{|l|l|l|l|l|}
\hline Isolate & Indole & Methyl red & Voges Proskauer & Citrate \\
\hline E.coli & +ve & +ve & -ve & -ve \\
\hline Citrobacter.sp & +ve & +ve & -ve & +ve \\
\hline
\end{tabular}

Out of the total 48 isolates obtained from 51 samples, a large proportion of E.coli has been isolated from sick or ailing calves irrespective of their age groups. The isolation of $E$. coli in high proportion may be related to the environment that are often inhaled or licked favouring a possible oronasal contamination (Poulsen and McGuirk, 2009). The findings are similar to Benesi et al., (2013). Staphylococcus aureus and Streptococcus bovis were isolated from three and two nasal samples of clinically sick calves respectively. Streptococcus bovis was isolated from the nasal mucosa of a sick calf when alive that later succumbed to severe respiratory distress. The gap between sampling and the death of the calf was four days. At the time of death the bacteria isolated from both nasal mucosa and lung was Citrobacter. sp. The change in the bacterial isolates possibly maybe due to the oronasal contamination from the environment (Poulsen and McGuirk 2009).

Moreover, frequent sampling indicated that the bacterial population in the nasal passages fluctuated in kinds and numbers with occasional periods (Barnum et al., 1969). Hartel et al., (2004) have isolated Staphylococcus aureus and Staphylococcus epidermidis from the nasal mucosa of healthy animals as well. Pasteurella mutocida has also been reported to be one of the important bacterial agents involved (Harper et al., 2006). Pasteurella multocida and Mannheimia haemolytica are normal components of the nasal bacterial microflora. They are opportunistic pathogens looking for a chance to invade and proliferate under stressful conditions (Seker et al., 2009). A switch from commensal to pathogen takes place when the organism proliferates due to variety of stress factors (Maheshswaran et al., 2002). As a result a clear correlation between the pathological changes and aetiology could not be established since the respiratory system has its own normal bacterial flora and the bacterial agents may co-exist in the same location. Stress might also lead to alteration of the mucosa of the respiratory tract (Taylor et al., 2010), adversely affecting the mucociliary clearance and thereby lowering the immunity of the animal. Young animals have low mucociliary clearance; leaving them more vulnerable to inhaled bacterial agents (Diesel et al., 1991).

Barnum et al., (1969) during a period of seven months surveyed on 790 samples of nasal mucous collected from calves in 12 herds using swab assembly. The basal flora was composed of potential pathogens that included Pasteurella multocida, Mannheimia haemolytica, Micrococcus, Neisseria and Streptococcus. Similarly Francoz et al., (2015) carried out a cross sectional study on ninety five preweaned calves from 11 dairy herds in Quebec and isolated Pasteurella multocida, Mannheimia haemolytica, Histophilus somni from 54, 17 and 12 calves respectively. However, the isolates obtained differ from the present findings.

Eleven calves succumbed to respiratory illness in between the sampling period. Necropsy examination was performed and all the dead calves showed signs of pneumonia. However, the maximum mortality was evident at 4-6 months of age. Svensson et al., 
2006 too reported calf mortality due to pneumonia at 1-6 months age which is closely similar to the present study. The gap between the clinical sampling and the death of the animals was wide except in one animal that died four days after manifesting severe respiratory symptoms at 9 months of age. The animal died of bronchopneumonia associated with presence of few lungworms. It can be deduced that either the respiratory infection in these animals had been existing in a subclinical form or these calves contracted mild infection after being introduced into the group pens. Calves housed in a group pen from 2 weeks of age have more inclination to suffer from respiratory diseases than calves housed in a single pen (Svensson et al., 2006; Svensson and Liberg, 2006). Waltner-Toews et al., (1986) and Hanekamp et al., (1994) also reported greater mortality of calves when kept in group pens. This is supported by the study conducted in United States by Pithua et al., (2009) where the calves kept in single cow calving pens experienced less disease incidences. The calves if kept in group pens should be of similar age with age difference not exceeding more than 56 days (Gulliksen et al., 2009b). The younger calves have the probability to catch infections from the older animals in larger herds due to aerosol route or nose to nose contact (Lago et al., 2006).

This study was mostly undertaken to determine the prevalence of bacterial isolates as no such work has been carried out in Himachal Pradesh so far. On bacterial isolation E.coli, Streptococcus. $\mathrm{sp}$, Staphylococcus. sp or Citrobacter. sp was isolated from nasal mucosa of clinically sick and apparently healthy calves. Advanced laboratory techniques can be implemented for identification of organism as the conventional method is laborious and more time consuming Mortality that occurred during the sampling period mostly occurred at the age of 4-6 months due to respiratory disease (pneumonia) especially during the winter season.

\section{Acknowledgements}

The authors express their gratitude to Mrs. Shweta, Mr. Krishan, Mr. Som Raj, Mr. Pritam and the Department of Pathology and Microbiology DGCN COVAS CSKHPAU, Palampur who took care of all the logistics necessary for the study. Special thanks to $\mathrm{Dr}$ V. Balena for the helpful advice and encouragement.

\section{References}

Barnum, D.A., Thomson, R.G. and Magwood, S.E., 1969. Nasal bacterial flora of calves in healthy and in pneumoniaprone herds. Canadian Journal of Comparative Medicine 33: 237-243

Benesi FJ, Bertagnon HG, Wachholz L, Leal MLR, Fernandes WA, Nilson BR and Melville PA. 2013. Bacterial microbiota and cytology of tracheobronchial region calves in the neonatal period. Pesquisa Veterinaria Brasileira 33(6): 700-704

Carter GR and Cole Jr JR. 1990. Diagnostic procedure in Veterinary Bacteriology and Mycology.

Chaudhary JK, Singh B, Prasad S and Verma MR. 2013. Analysis of morbidity and mortality rates in Bovines in Himachal Pradesh. Veterinary World 6(9): 614619

Diesel DA, Jack LL and Tucker A. 1991. Pulmonary particle deposition and airway mucociliary clearance in coldexposed calves. American Journal of Veterinary Research 52: 1665-1671

Francoz D, Buczinski S, Belanger AM, Forte G, Labrecque O, Tremblay D, Wellemans V and Dubuc J. 2015. Respiratory pathogens in Quebec dairy calves and their relationship with 
clinical status, lung consolidation and average daily gain. Journal of Veterinary Internal Medicine 29: 381387

Gulliksen S, Lie K, Loken T and Osteras O. 2009a. Calf mortality in Norwegian dairy herds. Journal of Dairy Science 92: 2782-2795

Gulliksen SM, Jor E, Lie KI, Loken T, Akerstedt J and Osteras O. 2009b. Respiratory infections in Norwegian dairy calves. Journal of Dairy Science 92: 5139-5146

Hanekemp WJA, Smits AC and Wierenga HK. 1994. Open versus closed barn and individual versus group housing for bull calves destined for beef production. Livestock Production Science 37: 261270

Harper M, Boyce JD and Adler B. 2006. Pausterella multocida pathogenesis: 125 years after Pasteur. FEMS Microbiology Letters 265: 1-10

Härtel H, Nikunen S, Neuvonen E, Tanskanen R, Kivelä S-L, Aho P, Soveri $\mathrm{T}$ and Saloniemi H. 2004. Viral and bacterial pathogens in bovine respiratory disease in Finland. Acta Veterinaria Scandinavica 45: 193-200

Lago A, McGuirk SM, Bennett TB, Cook NB and Nordlund KV. 2006. Calf Respiratory Disease and Pen Microenvironments in Naturally Ventilated Calf Barns in winter. Journal of Dairy Science 89: 4014-4025

Mahendra DS. 2014. Small farmers in India: Challenges and opportunities.

Maheswaran SK, Thumbikat $\mathrm{P}$ and Dileepan T. 2002. Current knowledge on pathogenesis of lung injury caused by Mannheimia haemolytica and Pasteurella multocida in the bovine. In: XXII World Buiatrics Congress, Hannover, Germany p 160-167

Mishra AK, Rawat NS, Nanawati S and Gaur AK. 2015. Studies on the calf mortality pattern in Gir breed. International Journal of Livestock Production 6(4): 47-51

NAHMS. 2007. Dairy 2007: Heifer Calf Health and management Practices on U.S. Dairy operations.

Pithua P, Wells SJ, Godden SM and Raizman EA. 2009. Clinical trial on type of calving pen and the risk of disease in Holstein calves during the first $90 \mathrm{~d}$ of life. Preventive Veterinary Medicine 89: 8-15

Poulsen KP and McGuirk SM. 2009. Disease of Bovine Neonate. Veterinary Clinics of North America: Food Animal Practice 25(1): 121-137

Prasad S, Ramachandran N and Raju S. 2004. Mortality Patterns in Dairy Animals under Organized Herd Management Conditions at Karnal India. Tropical Animal Health and Production 36 (7): 645-654

Radostits OM. 2001. Herd health: Food animal production medicine, $3^{\text {rd }}$ edition. p 333-390

Ramakrishna C, Srivastava N, Chaturvedi VB and Bhanuprakash V. 2008. Mortality pattern of the cross-bred dairy calves at the sub-Himalayan temperate region. Indian Veterinary Journal 85(12): 1316-1318

Seker E, Kuyucuoglu Y and Konak S. 2009. Bacterial examinations of the nasal cavity of apparently healthy and unhealthy Holstein cattle. Journal of Animal and Veterinary Advances 8(11): 2355-2359

Singh DD, Kumar M, Choudhary PK and Singh HN. 2009. Neonatal calf mortality - an overview. (Special issue: Veterinary paediatrics). Intas Polivet 10(2): 165-169

Svensson C and Liberg P. 2006. The effect of group size on health and growth rate of Swedish dairy calves housed in pens 
with automatic milk-feeders. Preventive Veterinary Medicine 73: 43-53

Svensson C, Linder A and Olsson SO. 2006. Mortality in Swedish dairy calves and replacement heifers. Journal of Dairy Science 89: 4769-4777

Taoudi A, Meier C and Amtsberg G. 1983. Prevalence of bacterial pathogens in post mortem material from calves. Der Praktische Tierarzt 64: 221-236

Taylor JD, Fulton RW, Lehenbauer TW, Step DL and Confer AW. 2010. The epidemiology of bovine respiratory disease: What is the evidence for preventive measures. Canadian Veterinary Journal 51:1351-1359

Trigo TE, Trigo TF, Hernandez LG, Ramirez CC and Berruecos VM. 1982. Pathology and bacteriology of calf pneumonia. Veterinaria Mexico 13: $131-140$
Veit HP and Farrel RL. 1978. The anatomy and physiology of the bovine respiratory system relating to pulmonary disease Cornell Veterinaria 68(4): 555-581

Virtala AMK, Mechor GD, Gröhn YT, Erb HN and Dubovi EJ. 1996. Epidemiologic and pathologic characteristics of respiratory tract disease in dairy heifers during the first 3 months of life. Journal of the American Veterinary Medical Association 208: 2035-2042

Waltner-Toews D, Martin SW and Meek AH. 1986. Dairy calf management, morbidity and mortality in Ontario Holstein herds. III. Association of management with morbidity. Preventive Veterinary Medicine 4: 13-158.

\section{How to cite this article:}

Stephanie S. Pradhan and Vipan Kumar Gupta. 2018. Identification and Characterization of Bacterial Isolates from Bovine Calves with Respiratory Affections. Int.J.Curr.Microbiol.App.Sci. 7(11): 1156-1164. doi: https://doi.org/10.20546/ijcmas.2018.711.134 